\title{
Molecular mechanisms underlying radioresistance: data compiled from isogenic cell experiments
}

\author{
Takahiro Oike ${ }^{1,2}$, Tatsuya Ohno ${ }^{1,2}$ \\ ${ }^{1}$ Department of Radiation Oncology, Gunma University Graduate School of Medicine, Gunma, Japan; ${ }^{2}$ Gunma University Heavy Ion Medical \\ Center, Gunma, Japan \\ Correspondence to: Takahiro Oike, MD, PhD. Associate Professor, Department of Radiation Oncology, Gunma University Graduate School of \\ Medicine, 3-39-22, Showa-machi, Maebashi, Gunma 371-8511, Japan. Email: oiketakahiro@gmail.com. \\ Provenance and Peer Review: This article was commissioned by the Editorial Office, Annals of Translational Medicine. The article did not undergo \\ external peer review. \\ Comment on: Zhou ZR, Wang XY, Yu XL, et al. Building radiation-resistant model in triple-negative breast cancer to screen radioresistance-related \\ molecular markers. Ann Transl Med 2020;8:108.
}

Submitted Jan 28, 2020. Accepted for publication Feb 27, 2020.

doi: $10.21037 / \mathrm{atm} .2020 .02 .90$

View this article at: http://dx.doi.org/10.21037/atm.2020.02.90

Radiotherapy is an essential component of cancer therapy. Theoretically, a sufficiently high dose of radiation should achieve complete tumor control. However, in threedimensional conformal radiotherapy (3D-CRT), which is a commonly used modality, the dose delivered to the tumor is often compromised to prevent adverse effects on normal tissues surrounding the tumor. Newer modalities such as intensity-modulated radiotherapy, stereotactic body radiotherapy, and particle radiotherapy can achieve higher dose conformality than 3D-CRT, leading to a higher dose delivery to the tumor. However, these highprecision radiotherapy modalities are less prevalent than 3D-CRT. Therefore, to maximize the efficacy of medical resources for radiotherapy as a whole, stratification of tumors based on photon sensitivity is crucial. This would lead to the preferential use of high-precision modalities for the treatment of relatively radioresistant tumors. To this end, the molecular mechanisms underlying cancer cell radioresistance need to be elucidated.

In a study published in January, 2020, in Annals of Translational Medicine (1), Zhou et al. performed fractionated $\mathrm{X}$-ray irradiation of a breast cancer cell line, MDAMB-231, and established a radioresistant subline as well as mouse xenografts. Comparison of gene expression profiles between the parental line and the radioresistant subline identified $C D K N 1 A$ and SOD2 as upregulated genes in the radioresistant cells. The authors also demonstrated that high CDKN1A/SOD2 expression could predict a poor prognosis for breast cancer patients. These data provide insight into the response of breast cancer to radiotherapy. In addition, the models developed are a useful tool for further investigation into this issue.

Zhou et al. (1) demonstrated that the establishment and analysis of isogenic radioresistant sublines is a powerful strategy to explore the mechanisms underlying cancer cell radioresistance, which has been the subject of research for decades (Table 1). Previous studies suggested resistance to apoptosis $(2,8-10,14,21,23)$ and high DNA repair capacity $(7,9,13,19,23)$ as candidate mechanisms. In addition, studies show an association between radioresistance and high cellular migration $(8,23,24)$ and antioxidant $(1,9,17)$ capacities. Regarding the signaling pathways involved, the MAPK $(18,22,24)$, PI3K $(18,20,22,24)$, and JAKSTAT $(12,22)$ axes consistently show increased activity in radioresistant cells. Activation of molecules associated with multi-drug resistance $(9,25)$ and epithelial-mesenchymal transition (11), alterations of cell cycle profiles $(1,23)$ and immune systems (16), and other mechanisms (3-6,15) have also been reported as possible mechanisms associated with radioresistance. These findings provide an important biological basis for understanding the mechanisms underlying radioresistance. However, there is considerable variation among studies in the establishment of radioresistant cell lines in terms of histology of the cell line and irradiation protocols (i.e., total dose, single dose, and irradiation interval) (Table 1). Cross-validation of the results 


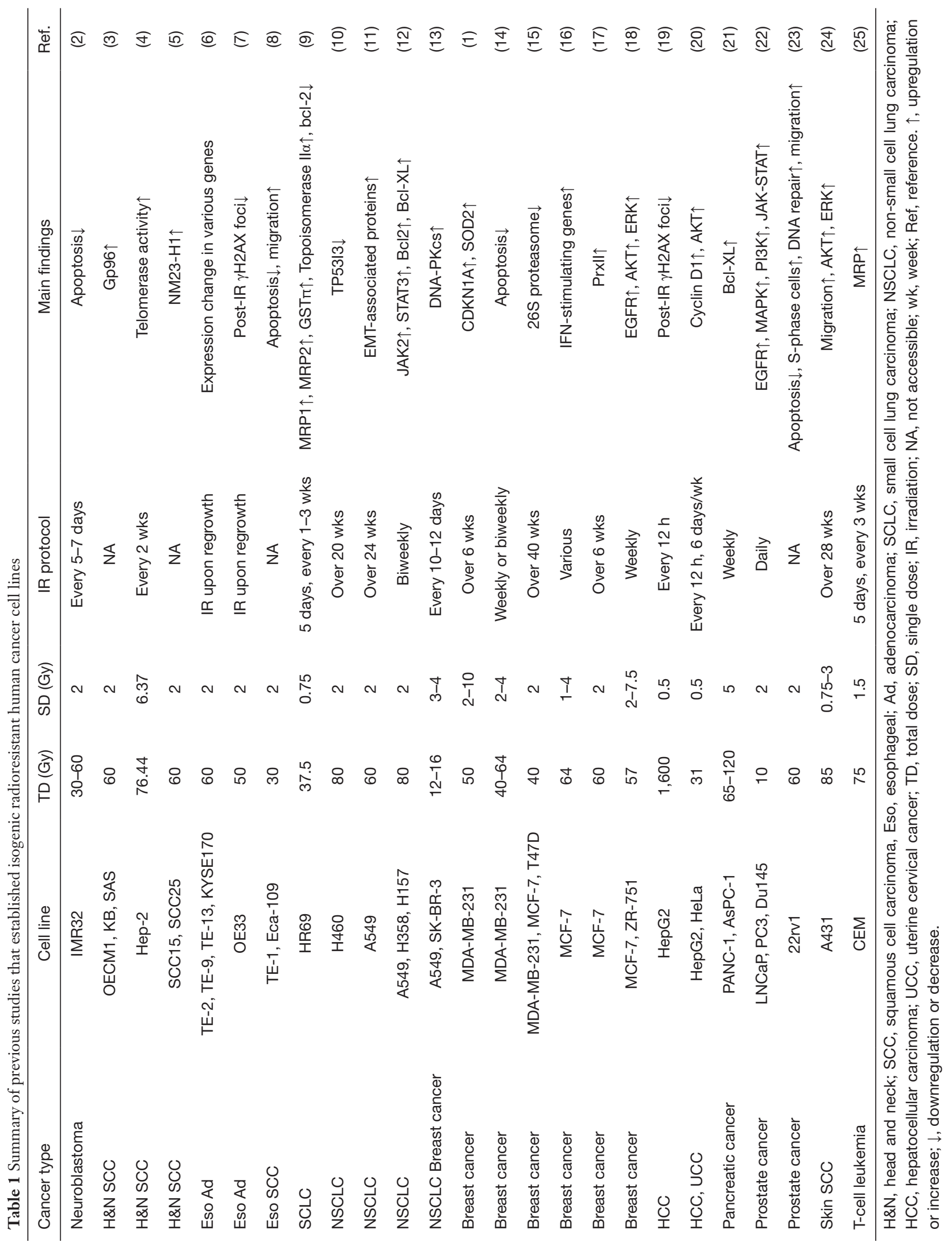


is necessary in the future to build robust evidence that can be translated to the clinic.

In summary, studies on isogenic radioresistant cell lines provide clues to understand the mechanisms underlying cancer cell radioresistance, which will facilitate personalization of radiotherapy.

\section{Acknowledgments}

Funding: This work was supported by Gunma University Heavy Ion Medical Center and by Grants-in-Aid from the Japan Society for the Promotion of Science for KAKENHI [19K17162].

\section{Footnote}

Conflicts of Interest: The authors have no conflicts of interest to declare.

Etbical Statement: The authors are accountable for all aspects of the work in ensuring that questions related to the accuracy or integrity of any part of the work are appropriately investigated and resolved.

Open Access Statement: This is an Open Access article distributed in accordance with the Creative Commons Attribution-NonCommercial-NoDerivs 4.0 International License (CC BY-NC-ND 4.0), which permits the noncommercial replication and distribution of the article with the strict proviso that no changes or edits are made and the original work is properly cited (including links to both the formal publication through the relevant DOI and the license). See: https://creativecommons.org/licenses/by-nc-nd/4.0/.

\section{References}

1. Zhou ZR, Wang XY, Yu XL, et al. Building radiationresistant model in triple-negative breast cancer to screen radioresistance-related molecular markers. Ann Transl Med 2020;8:108.

2. Russell J, Wheldon TE, Stanton P. A radioresistant variant derived from a human neuroblastoma cell line is less prone to radiation-induced apoptosis. Cancer Res 1995;55:4915-21.

3. Luo J, Wang W, Tang Y, et al. mRNA and methylation profiling of radioresistant esophageal cancer cells: the involvement of Sall2 in acquired aggressive phenotypes. J Cancer 2017;8:646-56.
4. Henness S, Davey MW, Harvie RM, et al. Fractionated irradiation of H69 small-cell lung cancer cells causes stable radiation and drug resistance with increased MRP1, MRP2, and topoisomerase IIalpha expression. Int J Radiat Oncol Biol Phys 2002;54:895-902.

5. Lee YS, Oh JH, Yoon S, et al. Differential gene expression profiles of radioresistant non-small-cell lung cancer cell lines established by fractionated irradiation: tumor protein p53-inducible protein 3 confers sensitivity to ionizing radiation. Int J Radiat Oncol Biol Phys 2010;77:858-66.

6. Pearce AG, Segura TM, Rintala AC, et al. The generation and characterization of a radiation-resistant model system to study radioresistance in human breast cancer cells. Radiat Res 2001;156:739-50.

7. Lee JU, Hosotani R, Wada M, et al. Role of Bcl-2 family proteins (Bax, Bcl-2 and Bcl-X) on cellular susceptibility to radiation in pancreatic cancer cells. Eur J Cancer 1999;35:1374-80.

8. McDermott N, Meunier A, Mooney B, et al. Fractionated radiation exposure amplifies the radioresistant nature of prostate cancer cells. Sci Rep 2016;6:34796.

9. Lynam-Lennon N, Reynolds JV, Pidgeon GP, et al. Alterations in DNA repair efficiency are involved in the radioresistance of esophageal adenocarcinoma. Radiat Res 2010;174:703-11.

10. Mihatsch J, Toulany M, Bareiss PM, et al. Selection of radioresistant tumor cells and presence of ALDH1 activity in vitro. Radiother Oncol 2011;99:300-6.

11. Kuwahara Y, Li L, Baba T, et al. Clinically relevant radioresistant cells efficiently repair DNA double-strand breaks induced by X-rays. Cancer Sci 2009;100:747-52.

12. de Llobet LI, Baro M, Figueras A, et al. Development and characterization of an isogenic cell line with a radioresistant phenotype. Clin Transl Oncol 2013;15:189-97.

13. Wang T, Tamae D, LeBon T, et al. The role of peroxiredoxin II in radiation-resistant MCF-7 breast cancer cells. Cancer Res 2005;65:10338-46.

14. Gray M, Turnbull AK, Ward C, et al. Development and characterisation of acquired radioresistant breast cancer cell lines. Radiat Oncol 2019;14:64.

15. Skvortsova I, Skvortsov S, Stasyk T, et al. Intracellular signaling pathways regulating radioresistance of human prostate carcinoma cells. Proteomics 2008;8:4521-33.

16. Shimura T, Kakuda S, Ochiai Y, et al. Acquired radioresistance of human tumor cells by DNA-PK/AKT/ GSK3beta-mediated cyclin D1 overexpression. Oncogene 2010;29:4826-37. 
17. You S, Li R, Park D, et al. Disruption of STAT3 by niclosamide reverses radioresistance of human lung cancer. Mol Cancer Ther 2014;13:606-16.

18. Harvie RM, Davey MW, Davey RA. Increased MRP expression is associated with resistance to radiation, anthracyclines and etoposide in cells treated with fractionated gamma-radiation. Int J Cancer 1997;73:164-7.

19. Shintani Y, Okimura A, Sato K, et al. Epithelial to mesenchymal transition is a determinant of sensitivity to chemoradiotherapy in non-small cell lung cancer. Ann Thorac Surg 2011;92:1794-804.

20. Post AEM, Smid M, Nagelkerke A, et al. InterferonStimulated Genes Are Involved in Cross-resistance to Radiotherapy in Tamoxifen-Resistant Breast Cancer. Clin Cancer Res 2018;24:3397-408.

21. Lin TY, Chang JT, Wang HM, et al. Proteomics of the radioresistant phenotype in head-and-neck cancer: Gp96

Cite this article as: Oike T, Ohno T. Molecular mechanisms underlying radioresistance: data compiled from isogenic cell experiments. Ann Transl Med 2020;8(6):273. doi: 10.21037/ atm.2020.02.90 as a novel prediction marker and sensitizing target for radiotherapy. Int J Radiat Oncol Biol Phys 2010;78:246-56.

22. Zhou FX, Xiong J, Luo ZG, et al. cDNA expression analysis of a human radiosensitive-radioresistant cell line model identifies telomere function as a hallmark of radioresistance. Radiat Res 2010;174:550-7.

23. Lee SY, Park HR, Cho NH, et al. Identifying genes related to radiation resistance in oral squamous cell carcinoma cell lines. Int J Oral Maxillofac Surg 2013;42:169-76.

24. Fukuda K, Sakakura C, Miyagawa K, et al. Differential gene expression profiles of radioresistant oesophageal cancer cell lines established by continuous fractionated irradiation. Br J Cancer 2004;91:1543-50.

25. Smith L, Qutob O, Watson MB, et al. Proteomic identification of putative biomarkers of radiotherapy resistance: a possible role for the $26 \mathrm{~S}$ proteasome? Neoplasia 2009;11:1194-207. 